\title{
Effects of Indole-3-Carbinol and Flavonoids Administered Separately and in Combination on Nitric Oxide Production and iNOS Expression in Rats
}

\author{
Evita Rostoka ${ }^{1}$, Larisa Baumane ${ }^{1}$, Sergejs Isajevs ${ }^{2}$, Aija Line $^{3}$, Karina Silina $^{3}$, Maija Dzintare ${ }^{1}$, \\ Darja Svirina $^{2}$, Jelena Sharipova ${ }^{1}$, Ivars Kalvinsh ${ }^{1}$, Nikolajs Sjakste ${ }^{1,2}$ \\ ${ }^{1}$ Latvian Institute of Organic Synthesis, Riga, Latvia \\ ${ }^{2}$ Faculty of Medicine, University of Latvia, Riga, Latvia \\ ${ }^{3}$ Latvian Biomedical Research and Study Centre, Riga, Latvia \\ E-mail: Nikolajs.Sjakste@lu.lv \\ Received January 20, 2010; revised April 29, 2010; accepted May 10, 2010
}

\begin{abstract}
Beneficial effects of natural compounds are often attributed to modulation of NO production; however effects produced by plant extracts do not correlate with effects of purified components. The goal of our work was to study ability of flavonoids and indole-3-carbinol, as well as their combinations to modify NO production, iNOS gene and protein expression in rat tissues. Baicalein and luteolin decreased NO concentration in both intact and LPS-treated animals. Baicalein decreased iNOS gene expression. Luteolin decreased NO production in the liver and heart and number of iNOS-positive cells in the liver of LPS-treated animals. Combination of the two substances did not decrease the NO synthesis triggered by LPS, although it decreased iNOS gene expression. Quercetin decreased NO production in the heart, kidneys and blood of intact rats, but enhanced the LPS effect in testes, spleen and blood on NO production and iNOS protein expression in the liver. Indole-3-carbinol decreased NO concentration in the cerebellum, blood, lungs and skeletal muscles. The drug enhanced the LPS-triggered increase of NO production in all rat organs. It increased iNOS protein expression in intact liver; however it decreased the LPS-triggered outburst of the enzyme biosynthesis. Combination of indole3-carbinol with quercetin decreased NO production in LPS-treated animals however it slightly increased iNOS gene expression. Taken together our results suggest that modifications of NO level in tissues by a natural compound cannot be predicted from data about its effects on NOS expression or activity. Combination of substances can produce an effect differing from that of individual substances. This stresses importance of direct measurements of $\mathrm{NO}$ in the tissues.
\end{abstract}

Keywords: Nitric Oxide, Baicalein, Luteolin, Indole-3-Carbinol, Quercetin, Inducible Nitric Oxide Synthase

\section{Introduction}

Natural biologically active compounds of plant origin including flavonoids are main active substances of traditional Chinese medicines: herbal extracts and similar preparations. Nowadays some of these substances are used in purified form as drugs. Anti-inflammatory activity, antioxidant activities, anticancer activity of phytogenic antineoplastic agents, and neuroprotective effects of Chinese herbal drugs are in focus of interest of many researchers worldwide [1]. Chinese traditional medicines are known to influence also nitric oxide enzymatic production and NO synthase activity [2]. It is supposed that flavonoid intake influences mortality from nitric oxide-dependent processes: ischemic heart disease, stroke, diabetes mellitus, and cancer [3], NO production is also modified by chemicals of plant origin [4]. This implies significance of flavonoid and other natural compound uptake for functions of cardiovascular, immune and nervous systems. However biological activity of polyphenol-rich food product does not correlate with effects that could be deduced from effects of individual compounds on NO synthase activity. For example, red wine is known as vasodilator [5], however purified quercetin, that is abundant in red wine inhibits iNOS gene expression $[6,7]$. It also destabilizes eNOS mRNA [8] and is 
even considered to be inhibitor of the NOS enzymatic activity [9]. Nevertheless the compound produces vasorelaxing effects [10] despite the fact that nitric oxide release in rat aorta is not detected after quercetin administration [11]. In this work we have studied the ability of several natural compounds of plant origin administered separately and in combinations to modify NO production in rat tissues monitored by ESR spectroscopy of $\mathrm{Fe}$ (DETC $)_{2}$-NO complexes conducted in parallel to evaluation of iNOS gene expression assayed by real-time RTPCR technique. Combination of direct NO detection in tissues with other approaches characterizing NO production at different levels enabled us to reveal unforeseen effects of presumable NO-donors, anaesthetics and an anti-ischemic drug [12-14]. The same approach was applied this time to natural compounds. Flavonoids luteolin, baicalein and quercetin as well as simple phenolic compound indole-3-carbinol were chosen among many other compounds after a piloting study.

Luteolin, 3', 4', 5, 7-tetrahydroxyflavone is abundant in vegetables: roots of celery, rutabaga, red pepper, spinach and flowering plants: Ajuga decumbens, Taraxacum officinale (dandelion), Medicago sativa (alfalfa). Luteolin is known as dietary compound with antioxidant activity [15]. Baicalein (5, 6, 7-trihydroxyflavone) is found in Scutellaria baicalensis Georgi roots. Quercetin (pentahydroxyflavonol) is found in numerous higher plants. This flavonol is abundant in onions, apples, leaf vegetables, beans, tea, red wine, clover, pollen. Indole-3-carbinol (3-indolmetanol) is found in Mustard family plants: (Brassica sp.): cabbage, broccoli, Brussels sprouts. The compound is widely studied as chemotherapeutic agent for cancer treatment [16]. Chemical structures of the compounds are given in Figure 1. Literature data indicated possible impact of all the three substances on NOS expression and/or NO production [15-22]. The chosen compounds are active substances in several drugs used in Chinese medicine. Quercetin is in important component of Shaofu Zhuyu decoction active extract [23], Saururus chinensis, a herb used traditionally in Chinese medicine for treatment of urological diseases [24], together with luteolin it is found in tree peony yellow flowers also widely used in Chinese medicine [25]. Baicalein is an active component of numerous Chinese medicines including Niu Huang Jie Du Pill [26].

The aims of the present work were: 1) To study effects NO production in several organs of intact rats and in LPS model of sepsis; 2) To reveal modifications of NO production by luteolin, baicalein, quercetin and indole-3carbinol given separately and in combinations in both intact and LPS-treated animals; 3) To study contribution of changes in iNOS gene and protein expression in modifications of NO production by natural compounds and their modifications.<smiles>O=c1cc(-c2ccc(O)c(O)c2)oc2cc(O)cc(O)c12</smiles><smiles>O=c1cc(-c2ccccc2)oc2cc(O)c(O)c(O)c12</smiles><smiles>O=c1c(O)c(-c2ccc(O)c(O)c2)oc2cc(O)cc(O)c12</smiles>

Indole-3-carbinol<smiles>OCc1c[nH]c2ccccc12</smiles>

Figure 1. Chemical structures of luteolin, baicalein, quercetin and indole-3-carbinole.

\section{Material and Methods}

\subsection{Chemicals}

Indole-3-carbinol, quercetin, baicalein and luteolin were purchased from Dayang Chemical Co., LTD (Hangzhou, China). Lipopolysaccharide, diethylthiocarbamate, ferrous sulfate, sodium citrate, TRI reagent and all other chemicals were from Sigma-Aldrich Chemie $\mathrm{GmbH}$ (Taufkirchen, Germany).

\subsection{Experiment Design and Drug Administration}

Animals were obtained from the Laboratory of Experimental Animals, Riga Stradins University, Riga, Latvia. All experimental procedures were carried out in accordance with guidelines of the Directive 86/609/EEC "European Convention for the Protection of Vertebrate Animals Used for Experimental and other Scientific Purposes" (1986) and were approved by the Animal Ethics Committee of the Food and Veterinary Service (Riga, Latvia).

Wistar male rats, each weighing $215.00 \pm 5.63 \mathrm{~g}$ at the beginning of the experiments, were used in all the work. The environment was maintained at a temperature of 22 $\pm 0.5^{\circ} \mathrm{C}$ with a 12 -h light/dark cycle. The animals were fed a standard laboratory diet. Description of the experimental groups is given in Table 1. In NO production experiments substances were administered per os in concentrations indicated in the Table 1. 3.5 hours after substance administration spin trap was injected, after $30 \mathrm{~min}$ 
Table 1. Description of groups and experiment design.

\begin{tabular}{|c|c|c|c|c|c|}
\hline $\begin{array}{l}\text { Group } \\
\text { number }\end{array}$ & $\begin{array}{l}\text { Number } \\
\text { of animals }\end{array}$ & Substance/dose & LPS & Parameter studied & Organs studied \\
\hline 1. & 24 & - & - & NO production & $\begin{array}{l}\text { Brain cortex, liver, heart, kidney, } \\
\text { blood, lungs }\end{array}$ \\
\hline 2. & 9 & Indole-3-carbinol (50 mg/kg) & - & NO production & $\begin{array}{l}\text { Brain cortex, liver, heart, kidney, } \\
\text { blood, lungs }\end{array}$ \\
\hline 3. & 5 & Luteolin $(50 \mathrm{mg} / \mathrm{kg})$ & - & NO production & $\begin{array}{l}\text { Brain cortex, liver, heart, kidney, } \\
\text { blood, lungs }\end{array}$ \\
\hline 4. & 6 & Quercetin $(50$ mg/kg) & - & NO production & $\begin{array}{l}\text { Brain cortex, liver, heart, kidney, } \\
\text { blood, lungs }\end{array}$ \\
\hline 5. & 5 & Baicalein $(50 \mathrm{mg} / \mathrm{kg})$ & & NO production & $\begin{array}{l}\text { Brain cortex, liver, heart, kidney, } \\
\text { blood, lungs }\end{array}$ \\
\hline 6. & 28 & - & $10 \mathrm{mg} / \mathrm{kg}$ & NO production & $\begin{array}{l}\text { Brain cortex, cerebellum, liver, } \\
\text { heart, kidney, blood, lungs, testes, } \\
\text { spleen, skeletal muscles }\end{array}$ \\
\hline 7. & 12 & Indole-3-carbinol (50 mg/kg) & $10 \mathrm{mg} / \mathrm{kg}$ & NO production & $\begin{array}{l}\text { Brain cortex, cerebellum, liver, } \\
\text { heart, kidney, blood, lungs, testes, } \\
\text { spleen, skeletal muscles }\end{array}$ \\
\hline 8. & 6 & Luteolin $(30$ mg/kg) & $10 \mathrm{mg} / \mathrm{kg}$ & NO production & $\begin{array}{l}\text { Brain cortex, cerebellum, liver, } \\
\text { heart, kidney, blood, lungs, testes, } \\
\text { spleen, skeletal muscles }\end{array}$ \\
\hline 9. & 6 & Quercetin $(50$ mg/kg) & $10 \mathrm{mg} / \mathrm{kg}$ & NO production & $\begin{array}{l}\text { Brain cortex, cerebellum, liver, } \\
\text { heart, kidney, blood, lungs, testes, } \\
\text { spleen, skeletal muscles }\end{array}$ \\
\hline 10. & 6 & Baicalein $(30 \mathrm{mg} / \mathrm{kg})$ & $10 \mathrm{mg} / \mathrm{kg}$ & NO production & $\begin{array}{l}\text { Brain cortex, cerebellum, liver, } \\
\text { heart, kidney, blood, lungs, testes, } \\
\text { spleen, skeletal muscles }\end{array}$ \\
\hline 11. & 8 & $\begin{array}{l}\text { Baicalein }(30 \mathrm{mg} / \mathrm{kg}) \\
\text { Luteolin }(30 \mathrm{mg} / \mathrm{kg})\end{array}$ & $10 \mathrm{mg} / \mathrm{kg}$ & NO production & $\begin{array}{l}\text { Brain cortex, cerebellum, liver, } \\
\text { heart, kidney, blood, lungs, testes, } \\
\text { spleen, skeletal muscles }\end{array}$ \\
\hline 12. & 6 & $\begin{array}{l}\text { Quercetin }(50 \mathrm{mg} / \mathrm{kg}) \\
\text { Indole-3-carbinol }(50 \mathrm{mg} / \mathrm{kg})\end{array}$ & $10 \mathrm{mg} / \mathrm{kg}$ & NO production & $\begin{array}{l}\text { Brain cortex, cerebellum, liver, } \\
\text { heart, kidney, blood, lungs, testes, } \\
\text { spleen, skeletal muscles }\end{array}$ \\
\hline 13. & 20 & - & - & iNOS mRNA and protein expression & Liver, brain cortex \\
\hline 14. & 3 & Indole-3-carbinol (50 mg/kg) & & iNOS mRNA and protein expression & Liver, brain cortex \\
\hline 15. & 3 & Luteolin $(50 \mathrm{mg} / \mathrm{kg})$ & & iNOS mRNA and protein expression & Liver, brain cortex \\
\hline 16. & 3 & Quercetin $(50$ mg/kg) & & iNOS mRNA and protein expression & Liver, brain cortex \\
\hline 17. & 3 & Baicalein $(50 \mathrm{mg} / \mathrm{kg})$ & & iNOS mRNA and protein expression & Liver, brain cortex \\
\hline 18. & 3 & $\begin{array}{l}\text { Quercetin }(50 \mathrm{mg} / \mathrm{kg}) \\
\text { Indole-3-carbinol }(50 \mathrm{mg} / \mathrm{kg})\end{array}$ & & iNOS mRNA and protein expression & Liver, brain cortex \\
\hline 19. & 3 & $\begin{array}{l}\text { Baicalein }(50 \mathrm{mg} / \mathrm{kg}) \\
\text { Luteolin }(50 \mathrm{mg} / \mathrm{kg})\end{array}$ & & iNOS mRNA and protein expression & Liver, brain cortex \\
\hline 20. & 21 & - & $10 \mathrm{mg} / \mathrm{kg}$ & iNOS mRNA and protein expression & Liver, brain cortex \\
\hline 21. & 6 & Indole-3-carbinol (50 mg/kg) & $10 \mathrm{mg} / \mathrm{kg}$ & iNOS mRNA and protein expression & Liver, brain cortex \\
\hline 22. & 6 & Luteolin $(50 \mathrm{mg} / \mathrm{kg})$ & $10 \mathrm{mg} / \mathrm{kg}$ & iNOS mRNA and protein expression & Liver, brain cortex \\
\hline 23. & 6 & Quercetin $(50$ mg/kg) & $10 \mathrm{mg} / \mathrm{kg}$ & iNOS mRNA and protein expression & Liver, brain cortex \\
\hline 24. & 6 & Baicalein $(50 \mathrm{mg} / \mathrm{kg})$ & $10 \mathrm{mg} / \mathrm{kg}$ & iNOS mRNA and protein expression & Liver, brain cortex \\
\hline 25. & 6 & $\begin{array}{l}\text { Quercetin }(50 \mathrm{mg} / \mathrm{kg}) \\
\text { Indole-3-carbinol }(50 \mathrm{mg} / \mathrm{kg})\end{array}$ & $10 \mathrm{mg} / \mathrm{kg}$ & iNOS mRNA and protein expression & Liver, brain cortex \\
\hline 26. & 6 & $\begin{array}{l}\text { Baicalein }(50 \mathrm{mg} / \mathrm{kg}) \\
\text { Luteolin }(50 \mathrm{mg} / \mathrm{kg})\end{array}$ & $10 \mathrm{mg} / \mathrm{kg}$ & iNOS mRNA and protein expression & Liver, brain cortex \\
\hline
\end{tabular}


rats were decapitated under slight ether narcosis. In several groups lipopolysaccharide $(10 \mathrm{mg} / \mathrm{kg})$ was intraperitoneally injected to rats, substances or their combinations were administered per os in the same time, spin traps were administered 3.5 hours later, 30 minutes after spin trap injection rats were decapitated under slight ether narcosis. In additional piloting series of experiments (not shown) iNOS inhibitor AMT (2 mg/kg), was administered intraperitoneally shortly before spin-trap administration, 30 minutes later rats were decapitated. For real-time PCR and immunochemistry rats were decapitated under slight ether narcosis; liver tissue was taken for RNA extraction and immunohistochemical examination. Brain cortex tissue was also taken from some animals for immunohistochemistry. Natural compounds and LPS were administered following the above time schedule.

\subsection{Administration of Spin Trap Agents}

To determine production level of nitric oxide in the tissues we used ESR spectroscopy of paramagnetic Fediethylthiocarbamate-nitric oxide complex (Fe (DETC) ${ }_{2}^{-}$ NO) [27]. Spin traps were administered 30 minutes before the sacrifice. Rats were administered $400 \mathrm{mg} / \mathrm{kg}$ of the nitric oxide scavenger diethylthiocarbamate via intraperitoneal injection and ferrous citrate subcutaneously (40 mg/kg ferrous sulphate $+200 \mathrm{mg} / \mathrm{kg}$ sodium citrate). Diethylthiocarbamate binds ferrous ion, the resulting complex traps nitric oxide converting to the paramagnetic Fe (DETC) $)_{2}$-NO complex that is detected by ESR spectroscopy.

\subsection{Sacrifice, Organ Dissection and Sample Preparation for Electron Paramagnetic Resonance Spectroscopy}

Following the drug and spin trap administration the rats were decapitated under slight ether anesthesia, samples of brain cortex, cerebellum, myocardium tissue, liver, kidney, testes, skeletal muscles, lungs and blood were compacted in a glass tube $30 \mathrm{~mm}$ in length with inner diameter $4 \mathrm{~mm}$ and immediately frozen in liquid nitrogen. Before recording the ESR spectra, the specimen was placed in a quartz finger Dewar flask ER 167 FDS-Q (Bruker, Karlsruhe, Germany) filled with liquid nitrogen.

\subsection{ESR Measurements}

ESR spectra were recorded in liquid nitrogen using an ESR spectrometer "Radiopan" SE/X2544 (Radiopan, Poznan, Poland). The conditions of the electron paramagnetic resonance measurements were: operation at X-band, $25 \mathrm{~mW}$ microwave power, $100 \mathrm{kHz}$ modulation frequency, $5 \mathrm{G}$ modulation amplitude, receiver gain $0.5 \times 10^{4}$, and time constant $1 \mathrm{~s}$. Spectra were recorded for 4 minutes. The nitric oxide content in the samples was evaluated from the height of the third component of the NO signal at $\mathrm{g}=2.031$.

The NO concentration (ng/g of tissue) was calculated on the basis of calibration curves as described previously. Briefly, different quantities of $\mathrm{NaNO}_{2}$ (final concentrations $10,20,30,40,60,100 \mathrm{M}$ ) were mixed with DETC $(33 \mathrm{mg} / \mathrm{mL})$ and $\mathrm{FeSO}_{4} \cdot 7 \mathrm{H}_{2} \mathrm{O}(3.3 \mathrm{mmol} / \mathrm{L})$, an excess of $\mathrm{Na}_{2} \mathrm{~S}_{2} \mathrm{O}_{4}(2 \mathrm{~mol} / \mathrm{L})$ was added to the mixture. The EPR spectra were taken as described above.

Further details are given in our previous publications [12-14,28-30].

\subsection{RNA Extraction and cDNA Preparation}

Total RNA was isolated from liver and brain cortex using TRI reagent (Sigma Aldrich, Taufkirchen, Germany). DNA contaminations were removed with RNA-free kit (Ambion, Austin, TX, USA). The resulting RNA quantity and purity were determined by spectrophotometry, integrity of RNA molecules was monitored by gel electrophoresis, and only specimens with well-pronounced rRNA bands were taken for reactions. RNA $(2 \mu \mathrm{g})$ was reverse-transcribed using a random hexamer primer (RevertAid $^{\text {TM }}$ First Strand cDNA Synthesis Kit, Fermentas, Vilnius, Lithuania) to obtain cDNA.

\subsection{Real Time RT-PCR}

The mRNA expression rates of the brain cortex, liver iNOS and reference gene were determined using the SYBR ${ }^{\circledR}$ Green PCR Master Mix (Applied Biosystems, Foster City, CA, USA) according to the instructions provided by the manufacturer. Amplification and detection of specific products were performed on a StepOne ${ }^{\mathrm{TM}}$ Real-Time PCR System (Applied Biosystems, Foster City, CA, USA) using the following temperature-time profile: one cycle of $95^{\circ} \mathrm{C}$ for $10.00 \mathrm{~min}$; and 40 cycles of $95^{\circ} \mathrm{C}$ for $0.15 \mathrm{~min}, 60^{\circ} \mathrm{C}$ for $1.00 \mathrm{~min}$. To check specificity of amplification products, the dissociation curve mode was used (one cycle at $95^{\circ} \mathrm{C}$ for $0.15 \mathrm{~min}, 60^{\circ} \mathrm{C}$ for $1 \mathrm{~min}$ and $95^{\circ} \mathrm{C}$ for $0.15 \mathrm{~min}$ ). To evaluate the suitability of candidates as reference genes, we applied the GeNorm program [31]. Primers were designed using Primer3 software. The primers were supplied by Metabion international AG, Germany. The $2^{-\Delta \Delta \mathrm{CT}}$ method was applied for analysis of the results. Primer sequences for iNOS gene were 5'-GCTACACTTCCAACGCAACA-3' for forward and 5'-CATGGTGAACACGTTCTTGG for reverse primer, the expected size of the product was $116 \mathrm{bp}$. RNA-polymerase II [32] was used as reference gene (5'GCCAGAGTCTCCCATGTGTT-3'and 5'-GTCGGTGG GACTCTGTTTGT-3', 135 bp). 


\subsection{Histological and Immunohistochemical Examination}

Paraffin-embedded tissue was cut in 4-micron-thick sections and stained with haematoxylin and eosin for morphological examination. Infiltration of inflammatory cells in brain tissue was assessed in subcortical perivascular, subcortical parenchymal, and intracortical peri-vascular regions (magnification $\times 400$ ). Perivascular infiltrates were defined as inflammatory cells, which are located not further than three cell layers from blood vessels. Inflammatory cells further than three layers from a blood vessel wall were defined as parenchymal infiltrates. Infiltration of inflammatory cells was assessed according to four score scale: $0-$ no infiltration; 1 - light infiltration; $2-$ medium infiltration; 3-marked infiltration; 4-very marked infiltration (more than $25 \%$ of the total field of vision).

The morphology of liver tissue was evaluated by evaluating the histological activity index (HAI), as described [33]: infiltration of inflammatory cells (0-4 scores); necrosis of hepatocytes around a central vein (0-6 scores); necrosis of hepatocytes and apoptosis in periphery lobules (0-4 scores); inflammatory changes of portal tracts (0-4 scores).

Tissue sections were stained for visualization of iNOS positive cells by an immunochemical approach as previously described [34]. Briefly, antigen retrieval was achieved by treatment in a microwave oven for $20 \mathrm{~min}$ at $300 \mathrm{~W}$ in citrate buffer, $\mathrm{pH}=6.0$. Endogenous peroxidase activity was blocked by $0.5 \% \mathrm{H}_{2} \mathrm{O}_{2}$ for $10 \mathrm{~min}$. Nonspecific primary antibody binding was blocked by serum-free protein block for $10 \mathrm{~min}$. Rabbit polyclonal active iNOS antibody Abcam Inc. (Cambridge, MA, USA) was applied in 1:200 dilution and incubated for $1 \mathrm{~h}$ at room temperature in a humidified chamber. Detection of primary antibody binding was performed using specific peroxidase conjugated polyclonal goat anti-rabbit IgG (1:100 for $30 \mathrm{~min}$ ) and subsequently peroxidase conjugated polyclonal rabbit anti-goat IgG (1:100 for 30 $\mathrm{min})$. The immunoperoxidase color reaction was developed by incubation with diaminobenzidine $(7 \mathrm{~min})$. A negative control without primary antibody was included in each staining run. iNOS positive cells were counted in twenty high-powered fields at magnification $\times 400$. All cell counts were expressed as cells per square millimeter. For morphological examination, at least 3 replicate measurements of iNOS positive cells were performed by the same observer in 10 randomly selected slides, and the intraobserver reproducibility was assessed with the coefficient of variation and with the interclass correlation coefficient. The intraobserver coefficient of variation was $4 \%$, and the intraobserver correlation coefficient was 0.94 .

\subsection{Statistical Analysis}

Results were expressed as mean \pm SD. The significance of differences in NO concentration and iNOS expression between groups was evaluated according to Student's unpaired $t$-test, the Mann-Whitney $U$ test was used for quantification of immunohistochemical experiments. Results were considered to be significant when $P$ was less than 0.05 .

\section{Results}

\subsection{Effects of Natural Compounds and their Combinations on NO Production in Intact and LPS-Treated Rats}

In order to test the ability of the natural compounds to modify NO production in animals the radical concentration was monitored in several rat organs and tissues. Data are summarized in Figure 2. ESR spectra of the different organs had a typical $\mathrm{Cu}$-DETC spectrum shape with a superposed $\mathrm{Fe}(\mathrm{DETC})_{2}-\mathrm{NO}$ peak, spectra were published previously [14]. The NO production reached the highest levels in the brain cortex, liver, lungs, and blood Figure 2. The NO production in heart and kidneys was an order of magnitude lower.

When control group of animals was compared to animals treated with natural substances it turned out that baicalein decreased NO concentration in heart, kidney, liver and lungs (Figure 2). Luteolin decreased NO production in the liver and heart. Quercetin induced significant decrease of NO production the heart, kidneys and blood. Indole -3-carbinol caused a significant decrease of NO production in the cerebellum, spleen, blood, lungs and skeletal muscles.

In the following set of experiments the eventual activity of the compounds as modifiers of NO production was tested against the background of the iNOS induction. Intraperitoneal injection of LPS to the animals caused a drastic increase of NO production levels in all tissues studied (Figure 2). The highest production of nitric oxide was detected in liver, whereas very strong increases in nitric oxide accumulation (50-100 fold compared to control) were observed in heart, blood and kidney. However, the effects of LPS were less pronounced in brain tissues where nitric oxide increased 4-6 times only. Nitric oxide production increase in testes was of comparable magnitude.

Baicalein $(30 \mathrm{mg} / \mathrm{kg})$ decreased NO concentration in brain cortex, liver, heart and kidneys. Luteolin $(30 \mathrm{mg} / \mathrm{kg})$ decreased NO outburst in all organs except skeletal muscles. In contrast, administration of the indole-3-carbinol $(50 \mathrm{mg} / \mathrm{kg})$ enhanced the LPS-induced increase of $\mathrm{NO}$ production in all organs except spleen and testes, Figure 2. Quercetin $(50 \mathrm{mg} / \mathrm{kg})$ produced similar effect: NO 


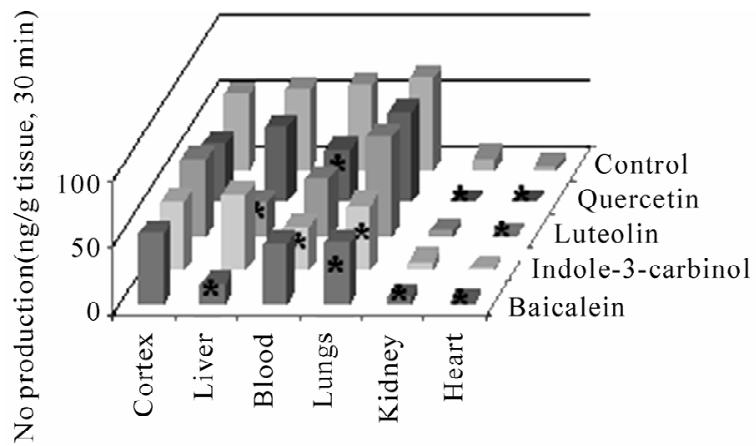

(a)

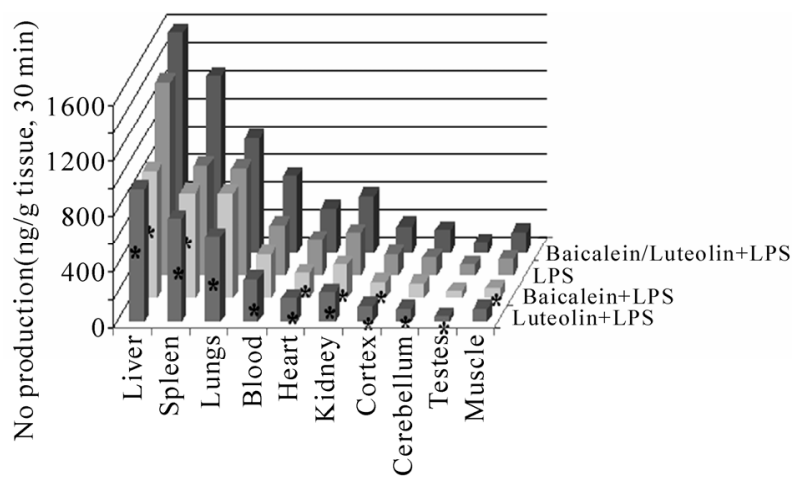

(b)

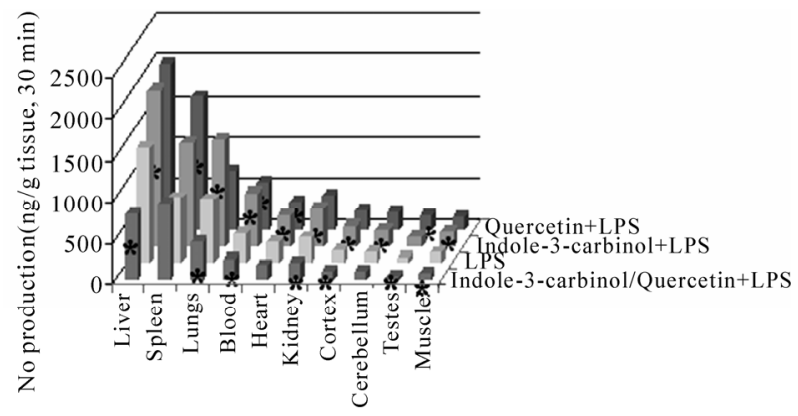

(c)

Figure 2. Effects of indole-3-carbinol, luteolin, baicalein quercetin and combinations of indole-3-carbinole + quercetin, baicalein + luteolin on NO production in rat organs of intact (a) and LPS-treated rats (b, c). Stars indicate statistically significant differences $(P<0.05)$ with control (a) or LPS (b, c) groups.

production increased in testes blood and spleen (Figure 2).

The observed ability of individual compounds to modify the LPS-triggered NO production raised the question about maintenance of the effects in presence of other substances. This approach modeled to some extent administration of flavonoid-containing herbal extracts. Baicalein as NO down-regulating and indole-3-carbinol as NO up-regulating substances were supplemented by luteolin and quercetin that produced NO-decreasing and NO-increasing effects correspondingly. Synergism of the effects was anticipated. Surprisingly, the results indi- cated adverse effects in both cases. Combination of indole3-carbinol with quercetin (50/50) decreased NO concentration up-regulated by LPS in many tissues. Similarly, combination of baicalein and luteolin lost the NO-decreasing activity characteristic of individual substances (Figure 2).

To test possible involvement of iNOS in the observed modifications natural substances were combined with iNOS inhibitor AMT (not shown). In intact animals the inhibitor markedly decreased NO production in all organs except the heart, AMT inhibiting action was attenuated by indole-3-carbinol in skeletal muscles. Quercetin also attenuated AMT effects in brain cortex, testes, blood and muscles. Luteolin slightly interfered with AMT action. These results indicated possible involvement of iNOS in effects of the compounds; this encouraged us to test ability of the substances to modify iNOS gene expression in rat liver.

\subsection{Effects of Natural Compounds on iNOS Gene mRNA Expression in Intact and LPS-Treated Rats}

No influence of indole-3-carbinol on iNOS expression in liver was observed (Figure 3). Surprisingly, luteolin upregulated the gene expression. Baicalein decreased level of the gene expression. Level of transcription was still decreased when baicalein was given in combination with luteolin. Quercetin did not produce any significant effect on iNOS gene transcription, a tendency for increase was observed when it was given in combination with indole-3-carbinol (Figure 3(a)).

The LPS effect on the gene expression in the liver was drastic (Figure 3(b)) as it could be predicted from the increase of NO production $(3442.82 \pm 761.24)$. However the effect was not well-reproducible between individual animals. Quercetin $(50 \mathrm{mg} / \mathrm{kg})$ significantly decreased the LPS-triggered iNOS mRNA expression. Enhancement of the iNOS mRNA expression by indole-3-carbinol was observed $(7715.01 \pm 1877.35 \%$ compared to control, the result is not statistically significant). The same trend was observed when indole-3-carbinol was supplemented by quercetin $(50 \mathrm{mg} / \mathrm{kg})$. Baicalein somewhat decreased the gene expression triggered by LPS, the effect was better pronounced if it was combined with luteolin (Figure 3(b)).

\subsection{Effects of Natural Compounds on iNOS Protein Expression in Intact and LPS-Treated Rats}

Data on effects of the tested compounds on number of iNOS positive cells in rat liver and brain cortex are given in Figures 4 and 5. Interestingly, indole-3-carbinol pro- 


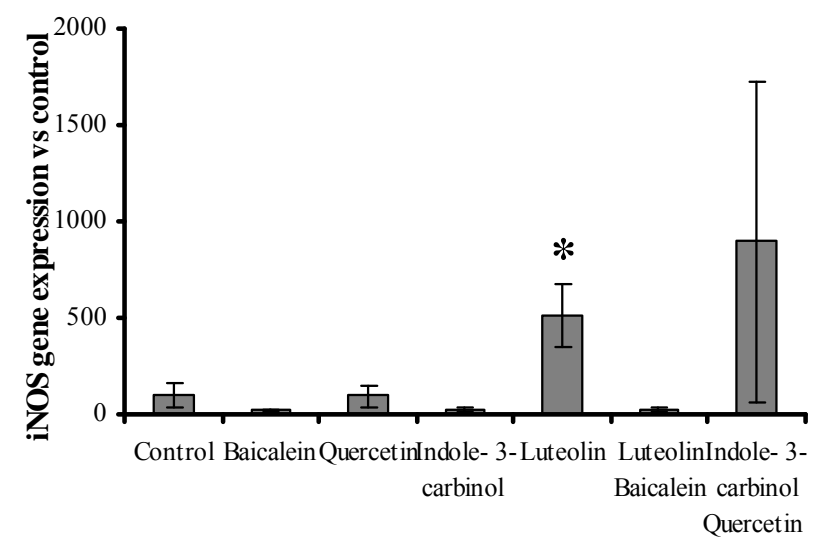

(a)

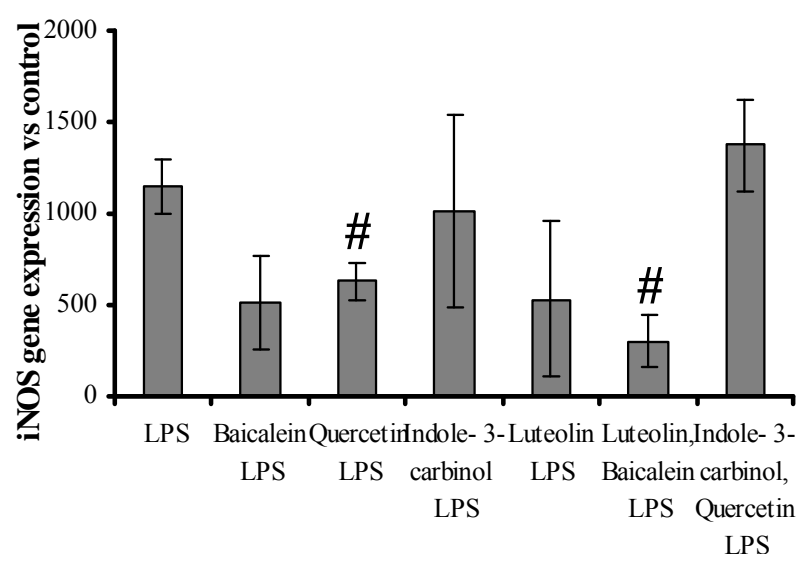

(b)

Figure 2. Effects of indole-3-carbinol, luteolin, baicalein quercetin and combinations of indole-3-carbinole + quercetin, baicalein + luteolin on iNOS gene expression in rat liver. Results are presented as percentage vs average of the control. (a) intact animals; (b) LPS-treated animals. All compounds were administered in dose $50 \mathrm{mg} / \mathrm{kg}$. *-P $<0.05$ versus control group, \#-P $<0.05$ versus $L P S$ group.

duced statistically significant increase of the protein expression; an effect is coherent with ESR data (Figure 2), the substance increased iNOS expression also in brain cortex (Figure 5(f)). Quercetin $(50 \mathrm{mg} / \mathrm{kg})$ and luteolin did not modify the protein expression level. Baicalein manifested a tendency to decrease number of iNOSpositive cells in the liver.

LPS significantly increased the number of iNOS positive cells in liver and brain cortex tissue. Indole-3-carbinol decreased outburst of iNOS protein translation triggered by LPS both in liver tissue (predominantly in Kupfer cells) and brain cortex tissue (Figures 5(c) and (g)), in this case immunohistochemistry data are in contradiction with ESR data indicating enhancement of LPS effects by the compound. Baicalein significantly decreased the LPS effect. On the contrary, quercetin enhanced expression of the enzyme in the liver of LPS-treated animals; this effect followed the trend observed in ESR experiments.

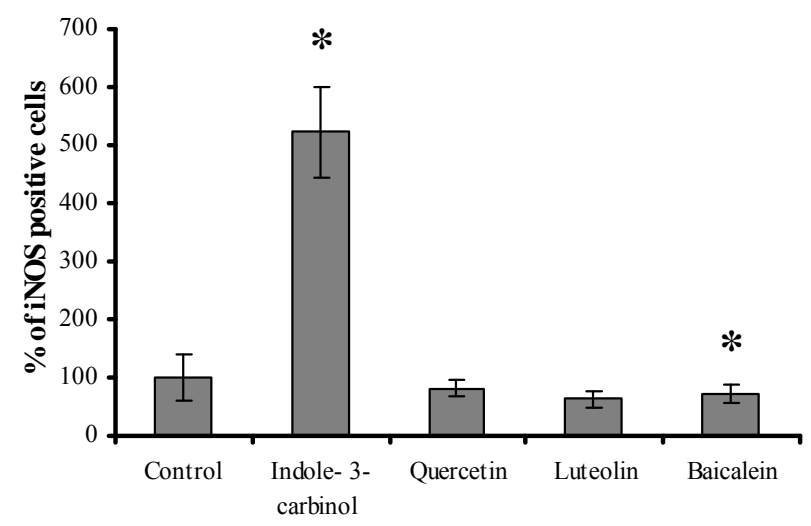

(a)

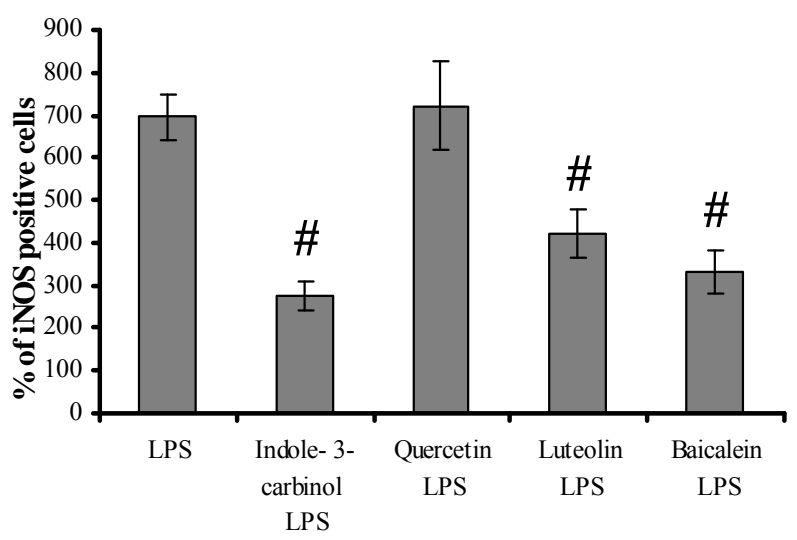

(b)

Figure 3. Effects of indole-3-carbinol, luteolin, baicalein and quercetin on number of iNOS-positive cells in rat liver. Results are presented as percentage vs average of the control. (a) intact animals; (b) LPS-treated animals. All compounds were administered in dose $50 \mathrm{mg} / \mathrm{kg}$. *_P $<0.05$ versus control group, \#-P $<0.05$ versus LPS group.

\section{Discussion}

\subsection{Baicalein and luteolin}

According published data baicalein suppresses iNOS gene expression in glia [35-37] and macrophages $[38,39]$ the inhibiting effect is achieved by decrease of lipoxine synthesis. In blood vessels this compound acts as antagonist of nitric oxide, it inhibits the soluble guanylate cyclase [40]. Baicalein depresses also the smooth muscle iNOS [41]. Luteolin is also is known as a weak inhibitor of iNOS expression, but it is not capable to inhibit the enzyme activity [17-20]. Some authors find that luteolin stimulates eNOS gene expression [21]. Apparently our results about decrease of NO concentration in some tissues after luteolin and baicalein administration are in good agreement with literature data, as this effect was observed both in intact and LPS-treated animals. Unexpectedly combination of the two compounds did not produce 


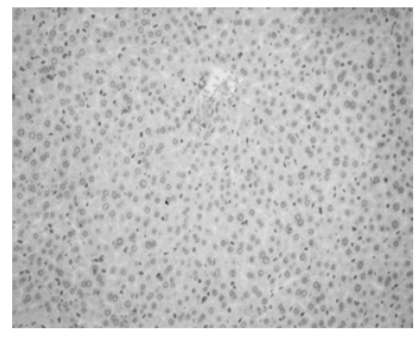

(a)

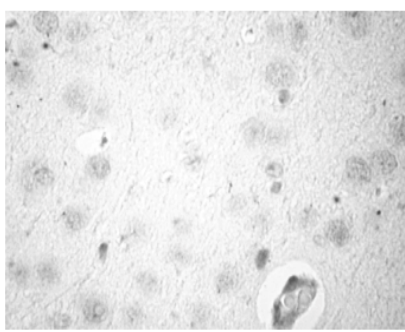

(e)

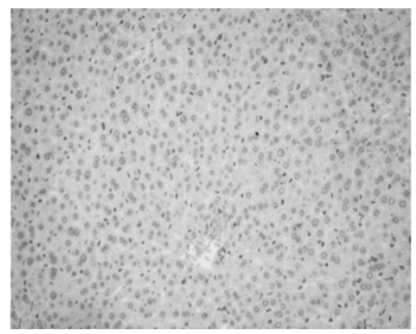

(b)

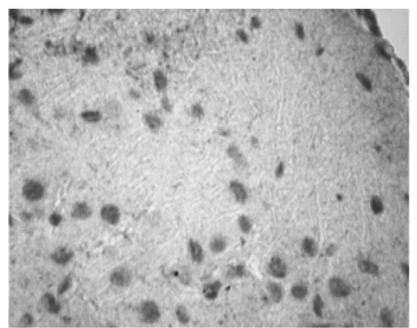

(f)

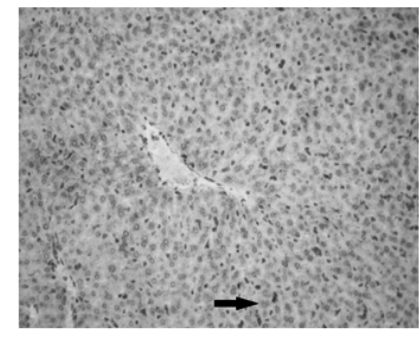

(c)

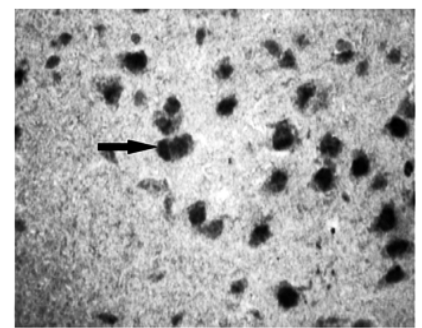

(g)

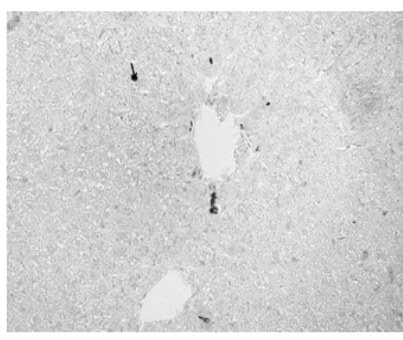

(d)

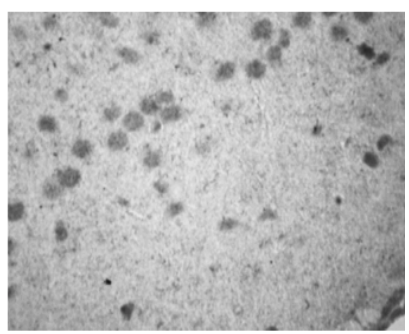

(h)

Figure 5. Photomicrographs of in rat liver tissue stained immunohistochemically with iNOS antibody (a-d), and brain cortex tissue (e-h). (a,e)-control, (b,f)-indole-3-carbinol, (c,g)-LPS at dose $10 \mathrm{mg} / \mathrm{kg}$; (d,h)-simultaneous administration of indole-3-carbinol and LPS. Arrows indicate iNOS positively stained cells. Magnification at $\times 100$ (a-d) and at $\times 400$ (e-h).

this effect. iNOS gene and protein expression was decreased by baicalein, this effect persisted when luteolin was administered to the same animal. Interestingly, Scutellaria baicalensis extract, i.e. combination of baicalein with other compounds increases NO synthesis in induced macrophages [42]. Interesting explanation can be proposed on the basis of hypothesis about nitrite protonation in acidic medium with generation of nitric acid. In this case flavonoids could reduce the acid to $\mathrm{NO}$ and stomach could turn into NO generator [43]. Simpler explanations can be also proposed. We have observed that higher dose of baicalein $(100 \mathrm{mg} / \mathrm{kg}$, not shown) produced less pronounced NO-lowering effect compared to a lower dose $(50 \mathrm{mg} / \mathrm{kg})$. Probably cytotoxic effect of the substances interferes with NO-modulating activity. Both baicalein and luteolin are inducers of apoptosis, the substances intercalate into DNA, inhibit topoisomerases I and II and DNA polymerase, induce TNF [44]. Thus apoptosis process can be triggered in many cells, NO level would increase as protection reaction against apoptosis [45].

\subsection{Indole-3-Carbinol and Quercetin}

Indole-3-carbinol is a weak iNOS induction inhibitor [22]. The substance interferes with several signaling pathways [46]. Decrease of NO concentration in blood, lungs and skeletal muscles caused by the substance can also indirectly indicate iNOS-inhibiting activity of the compound. Surprisingly, inverse effect was observed when we assessed number of iNOS-positive cells in the liver of intact rats. The compound enhanced increase of the gene transcription triggered by LPS in the liver, NO production in liver of intact animals and the LPS-induced increase of NO production in all the organs studied, amazingly, number of iNOS-positive cells in the liver of LPS-treated animals dropped down after administration of the substance. Thus the substance can either increase or decrease NO production in rat tissues. The effect depends on the tissue and physiological state of the animal. The NO decreasing activity of indole-3-carbinol can be explained by its capability to reduce NF-kB DNA binding activity $[16,46]$. Moreover the substance was shown to inhibit Akt-kinase activity, this leads to decrease of NF-kB expression $[16,46]$. Ability of the compound to increase the NO production in some organs, especially in LPS-treated animals could be rather ascribed to antioxidant activity of indole-3-carbinol [22]. Scavenging of reactive oxygen species prevents involvement of $\mathrm{NO}$ in interaction with these radicals increasing its bioavailability. This effect is produced by several natural compounds including cocoa polyphenols [47] and resveratrol [48]. Increase of enzyme expression by the drug indicates existence of some mechanism for regulation on transcription level. Enhancement by the substance of nitric oxide production induced by lypopolysaccharide upregulation of protein kinase $\mathrm{C}$ is also quite possible [49,50].

Quercetin decreased NO concentration in the heart, kidneys and blood; however it enhanced the LPS effect in testes, blood and spleen. The substance attenuated the LPS effects on the level of iNOS gene expression, however it enhanced these effects on protein expression level. Data about quercetin impact on NO synthesis are rather 
contradictory. The substance inhibits iNOS induction, the effect is better detectable in in vitro cultured cells $[6,7,51]$. In vivo quercetin did not decrease NFkB activation in kidney cortex [52]. In systems, where iNOS expression decrease by quercetin was observed, the flavonoid did not down-regulate NFkB activation [7,53]. Probably, quercetin interferes with tyrosin kinase-mediated pathways [54], and decreases TNF $\alpha$ expression [55]. However other authors observed the quercetin-induced inhibition of $\mathrm{IkB} \alpha$ (inhibitor of kappa B alpha) degradation via depression of IkB kinase activity, this leads to inhibition of NFkB [56]. Other reports inform about prevention and/or inhibition of IkB phosphorylation [57, 58], depression of NFkB activation by interleukin [59] and hydrogen peroxide [60] produced by the flavonoid. Inhibition of iNOS expression by quercetin is often ascribed to inhibition of the NFkB pathway [61,62]. Interestingly, some authors [63] find out that quercetin does not inhibit iNOS gene expression; however it inhibits iNOS enzyme expression. We came up to quite an opposite conclusion; however both the cited and our data indicate separate mechanisms for regulation of the iNOS gene and protein expression by this substance. Quercetin also destabilizes eNOS mRNA [8]. There are even data about ability of the substance to inhibit NOS enzymatic activity [9]. In the same time quercetin protects epithelium against lesions produced by NOS inhibitors [64] and stimulates NO synthesis in leukemia cells as protection reaction against induction of apoptosis [45]. Quercetin is considered to be the main active compound of red wine; some authors have observed NO-dependent vasorelaxation induced by quercetin [10]. Supplementation of diet with quercetin favors NO production in endothelium [5]. However the nitric oxide release from endothelium was not detected in special studies [11]. Quercetin is also one of the active substances of the Gingko biloba extracts, both purified quercetin and Gingko biloba extracts (i.e. mixture of quercetin with other natural compounds) decrease LPS-induced iNOS expression, however the extract acts via NF-kB inhibition, but quercetin inhibits TNFa pathway $[65,66]$. In our studies quercetin increased the LPS-triggered NO outburst in lungs, testes and lungs. Apparently, the NOS-inhibiting effect was not detectable on organism level. Our data contradict formerly published reports about decrease of nitrite production in brain [67] and blood plasma of LPS-treated animals [68] or streptozotocin-treated animals [69] by quercetin. However nitrite and NO production levels do not always correlate. When NO production was assessed by an approach similar to ours the quercetin-induced increase of $\mathrm{NO}$ production in rat brain was also observed [70]. Moreover the substance did not modify much iNOS gene expression in both healthy and LPS-treated animals. This effect can be associated with apoptosis-promoting activity of quercetin [71]. Probably simultaneous administration of indole-3-carbinol and quercetin favored manifestation of NOS-inhibiting activity of quercetin and abolished increase of NO bioavailability produced by indole-3-carbinol, as no decrease of iNOS expression was observed in this case. NO scavenging activity of quercetin [69-73] also could manifest itself in this case.

\section{Conclusions}

Taken together our results suggest that modifications of NO level in tissues by the studied natural compounds cannot be predicted from data about its effects on NOS expression or activity. Effects of individual compounds are not additive when these are administered in combination. This stresses importance of direct measurements of NO in the tissues using ESR method.

\section{Acknowledgements}

This study was supported in part by the National Reserach Program 2010.10.-4/VPP4 "Creation of novel means and methods for prophylaxis, treatment and diagnostics, elaboration of biomedical technologies for improvement of social health" and the grant 04.1317 "Pathological production of nitric oxide, possibilities of its pharmacological correction" awarded to N. Sjakste by the Latvian Council of Science. We thank L. Lauberte for technical assistance. Participation of D. Meirena in experiment design and discussion is greatly appreciated.

\section{References}

[1] H. Y. Li, L. Cui and M. Cui, "Hot Topics in Chinese Herbal Drugs Research Documented in PubMed/Medline by Authors inside China and Outside of China in the Past 10 Years: Based on Co-Word Cluster Analysis," Journal of Alternative and Complementary Medicine, Vol. 15, No. 7, 2009, pp. 779-785.

[2] H. Zeng, X. Liu, S. Dou, W. Xu, N. Li, X. Liu, W. Zhang, Z. Hu and R. Liu, "Huang-Lian-Jie-Du-Tang Exerts AntiInflammatory Effects in Rats through Inhibition of Nitric Oxide Production and Eicosanoid Biosynthesis via the Lipoxygenase Pathway" Journal of Pharmacy and Pharmacology, Vol. 61, No. 2, 2009, pp. 1699-1707.

[3] V. Bayard, F. Chamorro, J. Motta and N. K. Hollenberg, "Does Flavanol Intake Influence Mortality from Nitric Oxide-Dependent Processes? Ischemic Heart Disease, Stroke, Diabetes Mellitus, and Cancer in Panama," International Journal of Medical Microbiology, Vol. 4, No. 1, 2007, pp. 53-58.

[4] C. A. Schmitt and V. M. Dirsch, "Modulation of Endothe Lial Nitric Oxide by Plant-Derived Products," Nitric Oxide, Vol. 21, No. 2, 2009, pp. 77-91.

[5] S. Benito, D. Lopez, M. P. Saiz, S. Buxaderas, J. Sanchez, P. Puig-Parellada and M. T. Mitjavila, "A Flavonoid-Rich Diet Increases Nitric Oxide Production in Rat Aorta," British Journal of Pharmacology, Vol. 135, No. 4, 2002, 
pp. 910-916.

[6] R. Olszanecki, A. Gebska, V. I. Kozlovski and R. J. Gryglewski, "Flavonoids and Nitric Oxide Synthase," Journal of Physiology and Pharmacology, Vol. 53, No. 4, 2002, pp. 571-584.

[7] B. H. Kim, S. M. Cho, A. M. Reddy, Y. S. Kim, K. R. Min and Y. Kim, "Down-regulatory Effect of Quercitin Gallate on Nuclear Factor-Kappa B-Dependent Inducible Nitric Oxide Synthase Expression in LipopolysaccharideStimulated Macrophages RAW 264.7," Biochemical Pharmacology, Vol. 69, No. 11, 2005, pp. 1577-1183.

[8] T. Wallerath, H. Li, U. Godtel-Ambrust, P. M. Schwarz and U. Forstermann, "A Blend of Polyphenolic Compounds Explains the Stimulatory Effect of Red Wine on Human Endothelial NO Synthase," Nitric Oxide, Vol. 12, No. 2, 2005, pp. 97-104.

[9] L. Luo, Q. Sun, Y. Y. Mao, Y. H. Lu and R. X. Tan, "Inhibitory Effects of Flavonoids from Hypericum Perforatum on Nitric Oxide Synthase," Journal of Ethnopharmacology, Vol. 93, No. 2-3, 2004, pp. 221-225.

[10] C. K. Chen and C. R. Pace-Asciak, "Vasorelaxing Activity of Resveratrol and Quercetin in Isolated Rat Aorta," General Pharmacology, Vol. 27, No. 2, 1996, pp. 363366.

[11] J. C. Stoclet, A. Kleschyov, E. Andriambeloson, M. Diebolt and R. Andriantsitohaina, "Endothelial NO Release Caused by Red Wine Polyphenols," Journal of Physiology and Pharmacology, Vol. 50, No. 4, 1999, pp. 535540.

[12] N. Sjakste, A. L. Kleschyov, J. L. Boucher, L. Baumane, M. Dzintare, D. Meirena, J. Sjakste, K. Sydow, T. Münzel and I. Kalvinsh, "Endothelium- and Nitric OxideDependent Vasorelaxing Activities of Gamma-Butyrobetaine Esters: Possible Link to the Antiischemic Activities of Mildronate," European Journal of Pharmacology, Vol. 495, No. 1, 2004, pp. 67-73.

[13] N. Sjakste, J. Sjakste, J. L. Boucher, L. Baumane, T. Sjakste, M. Dzintare, D. Meirena, J. Sharipova and I. Kalvinsh, "Putative Role of Nitric Oxide Synthase Isoforms in the Changes of Nitric Oxide Concentration in Rat Brain Cortex and Cerebellum Following Sevoflurane and Isoflurane Anaesthesia," European Journal of Pharmacology, Vol. 513, No. 3, 2005, pp. 193-205.

[14] N. Sjakste, V. G. Andrianov, J. L. Boucher, I. Shestakova, L. Baumane, M. Dzintare, D. Meirena and I. Kalvins, "Paradoxical Effects of Two Oximes on Nitric Oxide Production by Purified NO Synthases, in Cell Culture and in Animals," Nitric Oxide, Vol. 17, No. 3-4, 2007, pp. 107-114.

[15] M. E. van Meeteren, J. J. Hendriks, C. D. Dijkstra and E. A. van Tol, "Dietary Compounds Prevent Oxidative Damage and Nitric Oxide Production by Cells Involved in Demyelinating Disease," Biochemical Pharmacology, Vol. 67, No. 5, 2004, pp. 967-975.

[16] K. M. Rahman, S. Ali, A. Aboukameel, S. H. Sarkar, Z. Wang, P. A. Philip, W. A. Sakr and A. Raz, "Inactivation of NF-kappaB by 3,3'-diindolylmethane Contributes to Increased Apoptosis Induced by Chemotherapeutic Agent in Breast Cancer Cells," Molecular Cancer Therapeutics, Vol. 6, 2007, pp. 2757-2765.

[17] S. J. Kim, H. Park and H. P. Kim, "Inhibition of Nitric Oxide Production from Lipopolysaccharide-Treated RAW 264.7 Cells by Synthetic Flavones: StructureActivity Relationship and Action Mechanism," Archives of Pharmacal Research, Vol. 27, No. 9, 2004, pp. $937-$ 943.

[18] J. S. Kim, H. J. Lee, M. H. Lee, J. Kim, C. Jin and J. H. Ryu "Luteolin Inhibits LPS-Stimulated Inducible Nitric Oxide Synthase Expression in BV-2 Microglial Cells," Planta Medica, Vol. 72, No. 1, 2006, pp. 65-68.

[19] C. Hu and D. D. Kitts, "Luteolin and Luteolin-7-O-glucoside from Dandelion Flower Suppress iNOS and COX-2 in RAW264.7 Cells," Molecular and Cellular Biochemistry, Vol. 265, 2004, pp. 107-113.

[20] L. S. Scuro, P. U. Simioni, D. L. Grabriel, E. E. Saviani, L. V. Modolo, W. M. Tamashiro and I. Salgado, "Suppression of Nitric Oxide Production in Mouse Macrophages by Soybean Flavonoids Accumulated in Response to Nitroprusside and Fungal Elicitation," BMC Medicine, Vol. 5, 2004, p. 5.

[21] H. Li, N. Xia, I. Brausch, Y. Yao and U. Forstermann, "Flavonoids from Artichoke (Cynara scolymus L.) upRegulate Endothelial-Type Nitric-Oxide Synthase Gene Expression in Human Endothelial Cells," Journal of Pharmacology and Experimental Therapeutics, Vol. 310, No. 3, 2004, pp. 926-932.

[22] C. Gerhäuser, K. Klimo, E. Heiss, I. Neumann, A. Gamal-Eldeen, J. Knauft, G. Y. Liu, S. Sitthimonchai and N. Frank, "Mechanism-based in Vitro Screening of Potential Cancer Chemopreventive Agents," Mutation Research, Vol. 523-524, 2003, pp. 163-172.

[23] S. Su, J. Guo, J. Duan, T. Wang, D. Qian, E. Shang and Y. Tang, "Ultra-performance Liquid Chromatography Tandem Mass Spectrometry Analysis of the Bioactive Components and their Metabolites of Shaofu Zhuyu Decoction Active Extract in Rat Plasma," Journal of Chromatography B Analytical Technologies in the Biomedical and Life Sciences, 2009. (in press)

[24] H. J. Chen, X. Li, J. W. Chen, S. Guo and B. C. Cai, "Simultaneous Determination of Eleven Bioactive Compounds in Saururus Chinensis from Different Harvesting Seasons by HPLC-DAD," Journal of Pharmaceutical and Biomedical Analysis, 2010. (in press)

[25] C. Li, H. Du, L. Wang, Q. Shu, Y. Zheng, Y. Xu, J. Zhang, J. Zhang, R. Yang and Y. Ge, "Flavonoid Composition and Antioxidant Activity of Tree Peony (Paeonia section moutan) Yellow Flowers," Journal of Agricultural and Food Chemistry, Vol. 57, No. 18, 2009, pp. 8496-8503.

[26] X. Liang, L. Zhang, X. Zhang, W. Dai, H. Li, L. Hu, H. Liu, J. Su and W. Zhang, "Qualitative and Quantitative Analysis of Traditional Chinese Medicine Niu Huang Jie Du Pill Using Ultra Performance Liquid Chromatography Coupled with Tunable UV Detector and Rapid Resolution Liquid Chromatography Coupled with Time-of-Flight Tandem Mass Spectrometry," Journal of Pharmaceutical 
and Biomedical Analysis, Vol. 51, No. 3, 2010, pp. 565571.

[27] A. L. Kleschyov, P. Wenzel and T. Münzel, "Electron Paramagnetic Resonance (EPR) Spin Trapping of Biological Nitric Oxide," Journal of Chromatography B Analytical Technologies in the Biomedical and Life Sciences, Vol. 851, No. 1-2, 2007, pp. 12-20.

[28] N. Sjakste, L. Baumane, D. Meirena, L. Lauberte, M. Dzintare and I. Kalvinsh, "Drastic Increase in Nitric Oxide Content in Rat Brain under Halothane Anesthesia, Revealed by EPR Method," Biochemical Pharmacology, Vol. 58, No. 12, 1999, pp. 1955-1959.

[29] L. Baumane, M. Dzintare, L. Zvejniece, D. Meirena, L. Lauberte, V. Sile, I. Kalvinsh and N. Sjakste, "Increased Synthesis of Nitric Oxide in Rat Brain Cortex Due to Halogenated Volatile Anesthetics Confirmed by ESR Spectroscopy," Acta Anaesthesiologica Scandinavica, Vol. 46, No. 4, 2002, pp. 378-383.

[30] E. Rostoka, L. Baumane, S. Isajevs, A. Line, M. Dzintare, D. Svirina, J. Sharipova, K. Silina, I. Kalvinsh and N. Sjakste, "Effects of Kaempferol and Myricetin on Inducible Nitric Oxide Synthase Expression and NO Production in Rats," Basic \& Clinical Pharmacology \& Toxicology, 2010. (in press)

[31] J. Vandesompele, K. De Preter, F. Pattyn, B. Poppe, N. Van Roy, A. De Paepe and F. Speleman, "Accurate Normalization of Real-Time Quantitative RT-PCR Data by Geometric Averaging of Multiple Internal Control Genes," Genome Biology, Vol. 18, 2002.

[32] A. Radonić, S. Thulke, I. M. Mackay, O. Landt, W. Siegert and A. Nitsche, "Guideline to Reference Gene Selection for Quantitative Real-Time PCR," Biochemical and Biophysical Research Communications, Vol. 313, No. 4, 2004, pp. 856-862.

[33] K. Ishak, A. Baptista, L. Bianchi, F. Callea, J. De Groote, J. Gudat, F. Gudat, H. Denk, V. Desmet, G. Korb, R. N. MacSween, "Histological Grading and Staging of Chronic Hepatitis," Journal of Hepatology, Vol. 22, No. 6, 1995, pp. 696-699.

[34] A. D. Stefano, G. Caramori, T. Oates, A. Capelli, M. Lusuardi, I. Gnemmi, F. Ioli, K. F. Chung, C. F. Donner, P. J. Barnes and I. M. Adcock, "Increased Expression of Nuclear Factor-kB in Bronchial Biopsies from Smokers and Patients with COPD," European Respiratory Journal, Vol. 20, 2000, pp. 556-563.

[35] J. S. Won, Y. B. Im, M. Khan, A. K. Singh and I. Singh, "Involvement of Phospholipase A2 and Lipoxygenase in Lipopolysaccharide-Induced Inducible Nitric Oxide SynThase Expression in Glial Cells," Glia, Vol. 51, 2005, pp. 13-21.

[36] C. J. Chen, S. L. Raung, S. L. Liao and S. Y. Chen "Inhibition of Inducible Nitric Oxide Synthase Expression by Baicalein in Endotoxin/Cytokine-Stimulated Microglia," Biochemical Pharmacology, Vol. 67, No. 5, 2004, pp. 957-965.

[37] K. Suk, H. Lee, S. S. Kang, G. J. Cho and W. S. Choi, "Flavonoid Baicalein Attenuates Activation-Induced Cell Death of Brain Microglia," Journal of Pharmacology and
Experimental Therapeutics, Vol. 305, No. 2, 2003, pp. 638-645.

[38] M. Vivancos and J. J. Moreno, "Role of $\mathrm{Ca}^{2+}$-Independent Phospholipase A(2) and Cyclooxygenase/Lip-Oxygenase Pathways in the Nitric Oxide Production by Murine Macrophages Stimulated by Lipopolysaccharides," Nitric Oxide, Vol. 6, No. 3, 2002, pp. 255-262.

[39] I. Wakabayashi, "Inhibitory Effects of Baicalein and Wogonin on Lipopolysaccharide-Induced Nitricoxide Production in Macrophages," Pharmacology \& Toxicology, Vol. 84, 1999, pp. 288-291.

[40] Y. Huang, C. M. Wong, C. W. Lau, X. Yao, S. Y. Tsang, Y. L. Su and Z. Y. Chen, "Inhibition of Nitric Oxide/Cyclic GMP-Mediated Relaxation by Purified Flavonoids, Baicalin and Baicalein, in Rat Aortic Rings," Biochemical Pharmacology, Vol. 67, No. 4, 2004, pp. 787-794.

[41] T. Hashimoto, M. Kihara, K. Yokoyama, T. Fujita, S. Kobayashi, K. Matsushita, K. Tamura, N. Hirawa, Y. Toya and S. Umemura, "Lipooxygenase Products Regulate Nitric Oxide and Inducible Nitric Oxide Synthase Production in Interleukin-1beta Stimulated Vascular Smooth Muscle Cells," Hypertension Research, Vol. 26, 2003, pp. 177-184.

[42] H. M. Kim, E. J. Moon, E. Li, K. M. Kim, S. Y. Nam and C. K. Chung, "The Nitric Oxide-Producing Activities of Scutellaria Baicalensis," Toxicology, Vol. 135, No. 2-3, 1999, pp. 109-115.

[43] U. Takahama, T. Oniki and S. Hirota, "Oxidation of Quercetin by Salivary Components. Quercetin-Dependent Reduction of Salivary Nitrite under Acidic Conditions Producing Nitric Oxide," Journal of Agricultural and Food Chemistry, Vol. 50, 2002, pp. 4317-4322.

[44] R. D. Snyder and P. J. Gillies, "Evaluation of the Clastogenic, DNA Intercalative, and Topoisomerase II-Interactive Properties of Bioflavonoids in Chinese Hamster V79 Cells," Environmental and Molecular Mutagenesis, Vol. 40, 2002, pp. 266-276.

[45] C. Kellner and S. J Zunino, "Nitric Oxide Is Synthesized in Acute Leukemia Cells after Exposure to Phenolic AntiOxidants and Initially Protects against Mitochondrial Membrane Depolarization," Cancer Letter, Vol. 215, No. 1, 2004, pp. 43-52.

[46] F. H. Sarkar and Y. Li, "Cell Signaling Pathways Altered by Natural Chemopreventive Agents," Mutation Research, Vol. 555, No. 1-2, 2004, pp. 53-64.

[47] H. Sies, T. Schewe, C. Heiss and M. Kelm, "Cocoa Polyphenols and Inflammatory Mediators," American Journal of Clinical Nutrition, Vol. 81, 2005, pp. 304S$312 \mathrm{~S}$.

[48] F. Orallo, E. Alvarez, M. Camiña, J. M. Leiro, E. Gómez and P. Fernández, "The Possible Implication of TransResveratrol in the Cardioprotective Effects of Long-Term Moderate Wine Consumption," Molecular Pharmacology, Vol. 61, No. 2, 2002, pp. 294-302.

[49] K. Fukuzawa, K. Kogure, M. Morita, S. Hama, S. Manabe and A. Tokumura, "Enhancement of Nitric Oxide and Superoxide Generations by Alpha-Tocopheryl Suc- 
cinate and its Apoptotic and Anticancer Effects," Biochemistry, Vol. 69, 2004, pp. 50-57.

[50] K. Kogure, M. Morita, S. Hama, S. Nakashima, A. Tokumura and K. Fukuzawa, "Enhancement by Alphato-Copheryl Hemisuccinate of Nitric Oxide Production Induced by Lypopolysaccharide and Interferon-Gamma through the Upregulation of Protein Kinase C in Rat Vascular Smooth Muscle Cells," European Journal of Biochemistry, Vol. 269, 2002, pp. 2367-2372.

[51] G. M. Raso, R. Meli, G. Di Carlo, M. Pacilio and R. D. Carlo, "Inhibition of Inducible Nitric Oxide Synthase and Cyclooxygenase-2 Expression by Flavonoids in Macrophage J774A.1,” Life Sciences, Vol. 68, 2001, pp. 921-931.

[52] G. K. Rangan, Y. Wang and D. C. Harris, "Dietary Quercetin Augments Activator Protein-1 and Does Not Reduce Nuclear Factor-Kappa B in the Renal Cortex of Rats with Established Chronic Glomerular Disease," Nephron, Vol. 90, No. 3, 2002, pp. 313-319.

[53] T. L. Wadsworth and D. R. Koop, "Effects of the Wine Polyphenolics Quercetin and Resveratrol on Proinflammatory Cytokine Expression in RAW 264.7 Macrophages," Biochemical Pharmacology, Vol. 57, No. 8, 1999 , pp. 941-949.

[54] S. Wang, V. L. DeGroff and S. K. Clinton, "Tomato and Soy Polyphenols Reduce Insulin-Like Growth Factor-IStimulated Rat Prostate Cancer Cell Proliferation and Apoptotic Resistance in Vitro via Inhibition of Intracellular Signaling Pathways Involving Tyrosine Kinase," Journal of Nutrition, Vol. 133, 2003, pp. 2367-2376.

[55] J. L. Pang, D. A. Ricupero, S. Huang, N. Fatma, D. P. Sing, J. S. Romero and N. Chattopadhyay, "Differential Activity of Kaempferol and Quercetin in Attenuating Tumor Necrosis Factor Receptor Family Signaling in Bone Cells," Biochemical Pharmacology, Vol. 71, No. 6, 2006, pp. 818-886.

[56] V. García-Mediavilla, I. Crespo, P. S. Collado, A. Esteller, S. Sánchez-Campos, M. J. Tunón and J. González-Gallego, "The Anti-Inflammatory Flavones Quercetin and Kaempferol Cause Inhibition of Inducible Nitric Oxide Synthase, Cyclooxygenase-2 and Reactive C-Protein, and DownRegulation of the Nuclear Factor Kappab Pathway in Chang Liver Cells," European Journal of Pharmacology, Vol. 557, No. 2-3, 2007, pp. 221-229.

[57] M. Comalada, D. Camuesco, S. Sierra, I. Ballester, J. Xaus, J. Galvez and A. Zarzuelo, "In Vivo Quercitrin Anti-Inflammatory Effect Involves Releases of Quercetin, Which Inhibits Inflammation through Down-Regulation of NF-Kappab Pathway," European Journal of Immunology, Vol. 35, 2005, pp. 584-592.

[58] M. P. Nair, S. Mahajan, J. L. Reynolds, R. Aalinkeel, H. Nair, S. A. Schwartz and C. Kandaswami, "The Flavonoid Quercetin Inhibits Proinflammatory Cytokine (Tumor Ne-Crosis Factor Alpha) Gene Expression in Normal Peripheral Mononuclear Cells via Modulation of the NF-KB System," Clinical and Vaccine Immunology, Vol. 13, 2006, pp. 319-328.

[59] K. Muraoka, K. Shimizu, X. Sun, T. Tani, R. Izumumi, K. Miwa and K. Yamamoto, "Flavonoids Exert Diverse In- hibitory Effects on the Activation of NF-kB," Transplantation Proceedings, Vol. 34, 2002, pp. 1335-1340.

[60] C. A. Musonda and J. K. Chipman, "Quercetin Inhibits Hydrogen Peroxide $\left(\mathrm{H}_{2} \mathrm{O}_{2}\right)$-Induced NF-kappaB DNA Binding Activity and DNA Damage in HepG2 Cells," Carcinogenesis, Vol. 19, No. 9, 1998, pp. 1583-1589.

[61] S. Martínez-Flórez, M. B. Gutiérrez S. Sánchez-Campos, J. González-Gallego and M. J. Tuñón, "Quercetin Prevents Nitric Oxide Production and Nuclear Factor Kappa B Activation in Interleukin-1B-Activated Rat Hepatocytes," Journal of Nutrition, Vol. 135, 2005, pp. 13591365.

[62] J. Chen, F. M. Ho, P. L. Chao, C. P. Chen, K. G. Jeng, H. B. Hsu, S. T. Lee, W. Wen Tung and W. W. Lin, "Inhibition of iNOS Gene Expression by Quercetin Is Mediated By the Inhibition of IKB Kinase, Nuclear Factor-Kappa B and STAT1, and Depends on Heme Oxygenase-1 Induction in Mouse BV-2 Microglia," European Journal of Pharmacology, Vol. 521, No. 1-3, 2005, pp. 9-20.

[63] T. Banerjee, A. Van der Vliet and V. A. Ziboh, "DownRegulation of COX-2 and iNOS by Amentoflavone and Quercetin in A549 Human Lung Adenocarcinoma Cell Line," Prostaglandins Leukot Essent Fatty Acids, Vol. 66, No. 5-6, 2002, pp. 485-492.

[64] J. Duarte, R. Jiménez, F. O'Valle, M. Galisteo, R. PérezPalencia, F. Vargas, F. Pérez-Vizcaíno, A. Zar-Zuelo and J. Tamargo, "Protective Effects of the Flavonoid Quercetin in Chronic Nitric Oxide Deficient Rats," Journal of Hypertension, Vol. 20, No. 9, 2002, pp. 1843-1854.

[65] T. L. Wadsworth and D. R. Koop, "Effects of Ginkgo Biloba Extract (EGb 761) and Quercetin on Lipopolysaccharide-Induced Release of Nitric Oxide," ChemicoBiological Interaction, Vol. 137, No. 1, 2001, pp. 43-58.

[66] T. L. Wadsworth, T. L. McDonald and D. R. Koop, "Effects of Ginkgo Biloba Extract (EGb 761) and Quercetin on Lipopolysaccharide-Induced Signaling Pathways Involved in the Release of Tumor Necrosis Factor-Alpha," Biochemical Pharmacology, Vol. 62, No. 7, 2001, pp. 963-974.

[67] H. M. Abd El-Gawad and A. E. Khalifa, "Quercetin, Coenzyme Q10, and L-canavanine as Protective Agents against Lipid Peroxidation and Nitric Oxide Generation in Endotoxin-Induced Shock in Rat Brain," Pharmacological Research, Vol. 43, No. 3, 2001, pp. 257-263.

[68] S. C. Shen, W. R. Lee, H. Y. Lin, H. C. Huang, C. H. Ko, L. L. Yang and Y. C. Chen, "In Vivo and In Vitro Inhibitory Activities of Rutin, Wogonin and Quercetin on Lipopolysaccharide-Induced Nitric Oxide and ProstaglanDin E(2) Production," European Journal of Pharmacology, Vol. 446, No. 1-3, 2002, pp. 187-194.

[69] O. Coskun, M. Kanter, A. Korkmaz and S. Oter, "Quercetin, a Flavonoid Antioxidant, Prevents and Protects Streptozotocin-Induced Oxidative Stress and BetaCell Damage in Rat Pancreas," Pharmacological Research, Vol. 51, No. 2, 2005, pp. 117-123.

[70] Z. Shutenko, Y. Henry, E. Pinard, J. Seylaz, P. Potier, F. Berthet, P. Girard and R. Sercombe, "Influence of the Antioxidant Quercetin in Vivo on the Level of Nitric 
Oxide Determined by Electron Paramagnetic Resonance in Rat Brain During Global Ischemia and Reperfusion," Biochemical Pharmacology, Vol. 57, No. 2, 1999, pp. 199-208.

[71] J. Da Silva, S. M. Hermann, V. Heuser, W. Peres, N. Marroni, J. González-Gallego and H. Erdtmann, "Evaluation of the Genotoxic Effect of Rutin and Quercetin by Comet Assay and Micronucleus Test," Food and Chemical Toxicology, Vol. 40, No. 7, 2002, pp. 941-947.
[72] M. Číž, M. Pavelková, L. Gallová, J. Králová, L. Kubala and A. Lojek, "The Influence of Wine Polyphenols on Reactive Oxygen and Nitrogen Species Production by Murine Macrophages RAW 264.7," Physiological Research, Vol. 57, 2008, pp. 393-402.

[73] S. Bastianetto, W. H. Zheng and R. Quirion, "Neuroprotective Abilities of Resveratrol and Other Red Wine Constituents against Nitric Oxide-Related Toxicity in Cultured Hippocampal Neurons," British Journal of Pharmacology, Vol. 131, No. 4, 2000, pp. 711-720. 